\title{
A NEW MODEL OF URBAN REGENERATION AND ECONOMIC REVITALISATION: THE I.D.E.A. DISTRICT, SAN DIEGO
}

\author{
Luana PARISI (10 ${ }^{1^{*}}$, Laura BIANCUZZO (1) ${ }^{2}$ \\ ${ }^{1}$ School of Architecture, Computing and Engineering, University of East London, London, United Kingdom \\ ${ }^{2}$ PAU Department, Mediterranea University of Reggio Calabria, Reggio Calabria, Italy
}

Received 25 February 2021; accepted 24 September 2021

\begin{abstract}
In the 21st century globalized economy, innovation is a crucial factor within strategies targeted at growing and sustaining competitiveness of regions and cities. The emerging trend of innovation-led urban planning initiatives provides strong evidence of how cities are implementing strategies to promote innovation mainstreaming. Hence, these innovationoriented policies are currently translated into the creation of innovation districts, becoming part of the urban settlement dynamics towards regeneration processes. This paper intends to explore the new paradigm of urban development initiatives driven by the increasing demand of innovation. Accordingly, innovation districts will be investigated by identifying the role, as well as the influence, of the different actors who nurture and accelerate the innovation process at urban level. The I.D.E.A. District case study will be examined, by pointing out the policies and planning initiatives undertaken in Downtown San Diego. Findings from this research will evaluate the effectiveness of the new generation of urban planning initiatives in supporting urban growth strategies. Additionally, the level of public private partnership effectiveness in supporting the development of innovation districts will be highlighted. Useful lessons can be drawn in encouraging planners and policymakers towards implementing these new innovation-oriented urban regeneration initiatives within urban growth strategies, important for enhancing competitiveness and for improving liveability by providing solutions for a more efficient land use.
\end{abstract}

Keywords: urban regeneration, economic development, innovation, public private partnership, innovation district model, multi-stage development.

\section{Introduction}

Over the last decades, innovation has increased its importance within the pattern of economic growth, moving to the central stage of policy makers' urban regeneration strategies targeted at growing and sustaining competitiveness in the 21st century globalized economy (West, 2011). Indeed, the creation of knowledge as a result of research and development efforts, as well as its commercialization and dissemination, are seen as an effective response to the pressures generated by globalization and the increasing international competition (Dahlman, 2007). Although an extensive body of knowledge corroborates the idea that innovation economy prefers regional innovation systems (Feldman, 1994; Asheim \& Gertler, 2006; Cortright, 2006; Sallet et al., 2009), the opinion that cities and innovation are strongly linked is becoming progressively popular (Shearmur, 2012). As a matter of fact, the urban environment has proven to provide a favourable context for innovative activities to prosper as demonstrated by the emerging trend of innovation districts proliferating globally. These refer to "geographic areas where leadingedge anchor institutions and companies cluster and connect with start-ups, business incubators, and accelerators. Compact, transit-accessible, and technically-wired, innovation districts foster open collaboration, grow talent, and offer mixed-used housing, office, and retail" (Katz \& Wagner, 2014). However, the occurrence of innovation is strictly related to a conducive innovation ecosystem characterized by a group of diverse agents, profit seeking, who generate and commercialize flows of knowledge, increasing the competitive advantage of the entire region (Metcalfe \& Ramlogan, 2008).

Considering that the innovation-oriented approach to urban regeneration is still a recent trend, so little empirical research has actually been conducted on the key role played by the actors who foster the innovation process at urban level, and their influence throughout the innovation

${ }^{\star}$ Corresponding author. E-mail: l.parisi2@uel.ac.uk 
district life cycle. This paper puts the body of knowledge forward on the triggering actions, implemented by city governments and investors, influencing the innovation space patterns, through the application of a life cycle assessment methodology. The systematic sequence of the framework here developed helps stakeholders visualise the combined actions at the different stages of an innovation district life cycle, highlighting the public private partnership effectiveness in supporting the successful development of innovation districts. Therefore, the paper attempts to build a useful framework for scrutinising the three-stage structure of the Design jobs cluster, nourished by Education, enriched by the Arts and focused on Innovation (I.D.E.A.) recently launched in Downtown San Diego, CA.

This paper is organized in five parts. Following this introduction, it illustrates the scientific background through an overview of the new geographical distribution of innovation characterised by the rise of innovation districts, which represent the physical environment where the dynamic innovation ecosystem takes shape. In the third part, the methodology that provides a breakdown of innovation district life cycle by step is presented, followed by the description of the case study. Next, the role played by public and private sector in the start-up, activation and maturing stages of the I.D.E.A. District development is analysed, and how these actions might affect the further planning practices is discussed. Finally, findings and conclusions are presented in the fifth part.

\section{Theoretical framework}

This paper aims to explore the new paradigm of urban development initiatives driven by the increasing demand of innovation. Accordingly, the creation of innovation districts is investigated by identifying the role, as well as the influence, of the different actors who nurture and accelerate the innovation process at urban level. The focus will be on the three stages of their development process. Three issues of the growing literature make a significant contribution to the understanding of the topic: (1) the literature exploring the geographical distribution of innovation, (2) studies illustrating the distinctive features of innovation districts, as well as (3) the reasons why a thriving innovation ecosystem is an essential requirement for districts creation.

\subsection{The urbanisation of innovation}

In recent times, the research on the geographical distribution of innovation has provided controversial views, confirming the complexity of the phenomenon; indeed, geographers and regional scientists devoted increasingly efforts in an attempt to disclose the proper spatial dimension of innovation and entrepreneurship, by investigating the dynamics that lead to define their geographical patterns.

Although an extensive body of knowledge corroborates the idea that innovation economy prefers regional innovation systems as location for creating and spreading new knowledge, so that generating well-performing cycles of innovation (Feldman, 1994; Asheim \& Gertler, 2006; Cortright, 2006; Sallet et al., 2009), the opinion that cities and innovation are strongly linked is becoming progressively popular (Shearmur, 2012). As a matter of fact, as Richard Florida et al. recently observed (2017), "innovation is highly concentrated across and within cities and metro areas". This new trend highlights how cities give a meaningful response to the challenges put forward by the 21st century globalized economy about the businesses critical choice of where to locate (Florida, 2008). The urban environment, indeed, has proven evidence to encompass the suitable economic and cultural dynamics in order to generate radical innovations and boost the development of new industries (Montgomery, 2012). It follows that, "innovation and entrepreneurship do not simply take place in cities but in fact require them" (Florida et al., 2017).

In addition, it has been demonstrated that cities allow innovation economy to reveal its potential in regenerating local economic areas and promoting local assets (Community Local Urban Development Laboratory, 2017). In this regard, the active role of innovation within urban development policies has been investigated by further reflections on the so-called innovative cities (Inkinen, 2015), which point out the massive transformations cities are experiencing by fostering "knowledge-intensiveness and technological advancement ... in order to become competitive providers of first class living for highly skilled global work-force".

All the above-mentioned observations lead to the conclusion that a process of urbanization of innovation is now occurring. A physical shift of innovative businesses from suburban corridors and science parks to inner-cities areas has taken place, prompted by companies' need to relocate in places that ensure close connectivity among people and give direct access to markets and finance, in order to support the innovative entrepreneurial activities. Cities are therefore seen as "hubs of technological innovation bringing together a wide range of sectors, deep international networks, customer and client opportunities, and cultural and artistic quality" (Mulas et al., 2015).

\subsection{The emerging trend of innovation districts}

The tangible effort of cities at providing a favourable context for innovation to prosper, can be read in the emerging trend of innovation districts proliferating globally. The 22@Barcelona District is considered the pioneer of this trend that paved the way to a multitude of innovationled regeneration projects, representing a successful model of planning and innovative urban design for several cities around the world.

The crucial factors behind the success of this newly conceived urban model can be easily deduced from the innovation district definition provided by an influential Brookings Institution report, edited by Katz and Wagner (2014), which refers to "geographic areas where 
leading-edge anchor institutions and companies cluster and connect with start-ups, business incubators, and accelerators. Compact, transit-accessible, and technicallywired, innovation districts foster open collaboration, grow talent, and offer mixed-used housing, office, and retail." It follows that, innovation districts all contain a powerful and unique combination of economic, physical, and networking assets which, brought together in geographic proximity, stimulate the idea generation facilitating the entrepreneurial activity (Giuffrida et al., 2015). Thus, this mixed-use approach has a fundamental role within a wider strategy of urban growth, in enhancing competitiveness by nurturing and accelerating the innovation process and improving liveability by providing solutions for a more efficient land use.

The relation that links innovation districts and physical environment has spurred debate in the literature, given its multi-dimensional and non-linear nature: innovation districts precisely reflect the city's wider economic, social and political systems, and they cannot flourish without the innovative ecosystem in which they are embedded, however, by contrast, innovation districts on their own do not generate any innovation ecosystem; moreover, districts could act as facilitators for such ecosystems to develop and expand, but at the same time they cannot operate as drivers of such ecosystems. As a consequence, the creation of innovation districts is the last stage of a process that starts with exploring the broad innovation economy, and then analysing the distinctive features of the city's innovation ecosystem, in order to assess the feasibility of an innovation district approach, which can achieve scale and strengthen critical mass just with the combined efforts of the private and public sector.

\subsection{The key role of a thriving innovation ecosystem}

As mentioned in the previous subsection, the presence of a favourable environment, namely innovation ecosystem, is an essential requirement for innovation to occur.

Ecosystem as an economic concept has been introduced by Moore (1996) to describe a business environment in which companies are forced to co-exist and interact with other organizations and individuals within their business ecosystem. The evident conceptual parallelism between biological and economic environment represents a leading line of research attempting to study the innovation ecosystem (Gobble, 2014), all culminating in a comprehensive and widely recognized definition which refers to "dynamic, purposive communities with complex, interlocking relationships built on collaboration, trust, and co-creation of value and specializing in exploitation of a shared set of complementary technologies or competencies. Strong innovation ecosystems translate knowledge into increased value, and they are resistant to disruption" (Autio \& Thomas, 2014).

In this process, design has a pivotal role in facilitating and nurturing innovation ecosystems and the spatial spots of innovation (Parisi, 2017). Thus, it is also important to

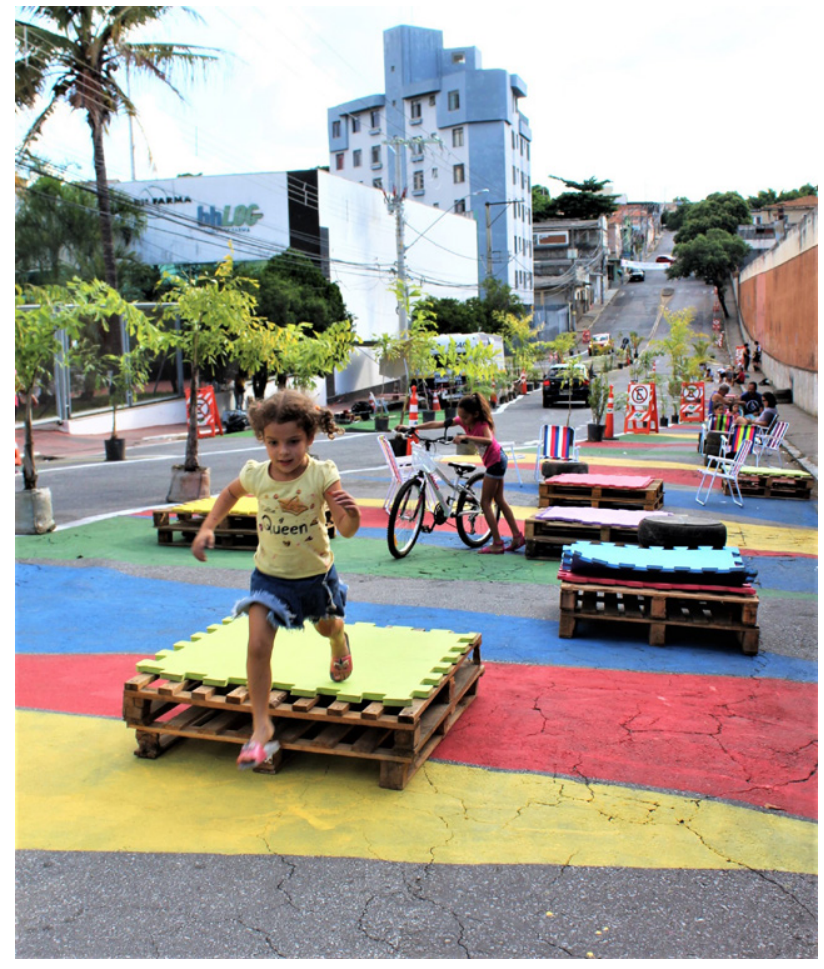

Figure 1. A tactical urbanism intervention in Brazil (Institute for Transportation and Development Policy, 2019)

consider immediate and temporary strategies of planning, by spurring, for instance, the use of tactical urbanism. These set of low-cost, temporary initiatives and transformations of the built environment aim to ameliorate local neighbourhoods and gathering spaces (Pfeifer, 2014).

The five main attributes characterizing these initiatives include a phased approach, a grasp of local ideas, a realistic and provisional commitment, a possible high reward with low uncertainties, an improvement of social capital together with a concerted effort between different institutions and associations (Lydon \& Garcia, 2015).

Cultural institutions also play an essential part in the innovation process. This has been well described by the triple helix model developed by Etzkowitz and Leydesdorff (1997), which ties together university-industry-government. Specifically, the approach explores the innovation dynamics by identifying universities as the engine of economic development within a knowledge society, given their ability to produce, transfer and apply knowledge; at the same time, small and medium-sized industries allow the production of new technologies in partnership with other organizations, while government sets the policy framework affecting the institutions behaviour in order to ensure constant and profitable interactions between the parties.

In sum, while evaluating the current state of the art for the body of knowledge reviewed, it became clear that innovation, through the creation of innovation districts in particular, is considered a strategy to enhance the competitiveness of cities and face the challenge put forward by the 21 st globalized economy. Still, the occurrence of 
innovation is strictly related to a conducive innovation ecosystem characterized by a group of diverse agents, profit seeking, who generate and commercialize flows of knowledge, increasing the competitive advantage of the entire region. However, a gap in research about the stages of innovation districts development of has been found. This paper puts forward the application of a framework designed to analyse the triggering actions, implemented by city governments and investors, influencing the innovation space patterns, in order to capture the abovementioned development process.

\section{Research methodology}

In the light of the findings raised above, the understanding of an innovation district life cycle can be best achieved by breaking down the process into the distinct phases that structure its development. Thus, after a brief introduction of the methodological framework adopted, the description of the I.D.E.A. District case studies will be presented.

\subsection{Three-stage development of innovation districts}

The following three-stage approach provides a framework broad enough to embrace the diverse contexts of innovation districts and the multiple actions of the stakeholders involved.

It allows the authors to effectively assess (1) the key role played by public and private sectors in nurturing the innovation ecosystem and in supporting specific locations as urban innovation districts (i.e. Start-up stage), (2) the

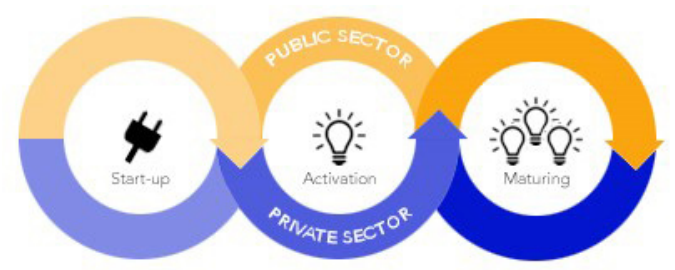

Figure 2. Framework to analyse the innovation district multistage development (Authors' elaboration) efforts to foster the ecosystem conditions and to catalyse development in a specific location (i.e. Activation stage); and finally, (3) the analysis of the strategies to sustain the environment for innovation as the district matures (i.e. Maturing stage).

According to the framework provided (Figure 1), the roles of public and private sectors in the different stages of the I.D.E.A. District development will be scrutinised.

\subsection{Case study description}

Following the 1980s Centre City Development Corporation's general strategy targeted at densifying specific parts of Downtown San Diego, in order to revitalise the "dormitory" character which distinguished most of the city centre, in 2010, developers David Malmuth and Pete Garcia brought forward the I.D.E.A. District as solution to create a vibrant city centre driven by a "Design jobs cluster, nourished by Education, enriched by the Arts and focused on Innovation" (I.D.E.A. District, 2011).

To implement the vision, 35 blocks located in the Upper East Village neighbourhood - traditionally home to a mixture of light industries and warehouses beginning to attract a large community of artisans and artists in the late 1990s - have been chosen, given the presence of several major educational institutions, such as the City College, the New School of Architecture and Design, the Urban Discovery Academy, the e3 Civic High, the FIDM and the Thomas Jefferson School of Law that emphasize design and multiple small but growing design-related businesses (Figure 2). Besides the presence of those notable anchor institutions, East Village showed a physical environment with the appropriate character to foster innovation activities: the compact neighbourhood consisted of small blocks that were easily walkable, the appropriate zoning and allowable density were already in place - following the Community Plan 2006 directives, and several vacant lots and empty warehouse buildings provided clues for the optimal building form for creative uses.

Thus, as stated by I.D.E.A. Partners, the undeniable convergence of technology and design, the presence of
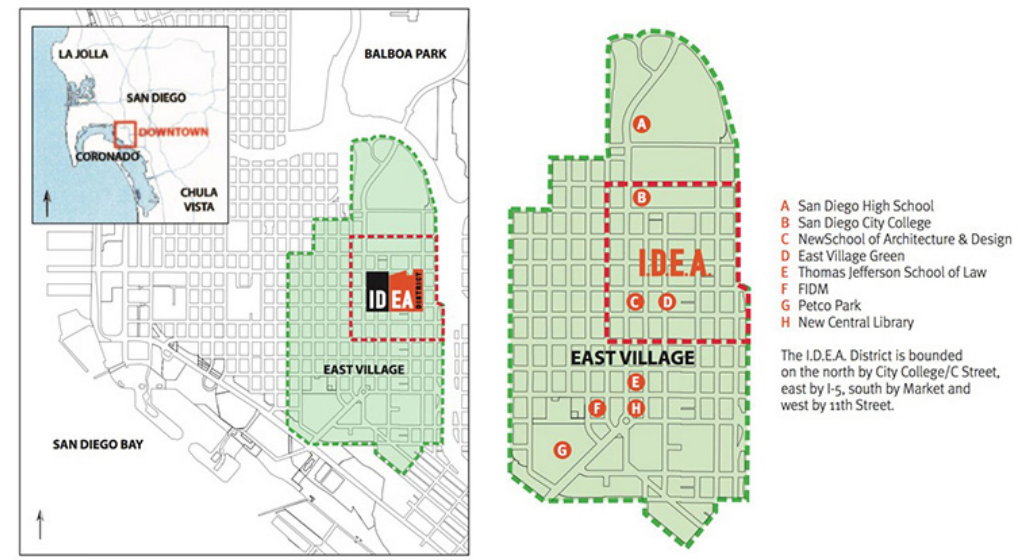

Figure 3. I.D.E.A. District location within San Diego's East Village

(I.D.E.A. District, 2011) 
growing design businesses and educational institutions hungry for collaboration, and available urban land with great "bones" all conspired to build an urban design vision, rather than a master plan, based on a new design industry cluster. This specific cluster has been chosen since design was considered to be a perfect complement to San Diego's already strong technology base, according to the principle that the most successful regions will not only grow new clusters, but they also understand how to facilitate collaboration across clusters (Delgado et al., 2014). Indeed, "the design process brings together art, technology, business, and science, integrating a range of considerations that are crucial to human potential, environmental sustainability, wealth creation and innovation" (DesignSingapore Council, 2008). In addition, the Connect Innovation Report (San Diego, 2010) emphasizes the capability of San Diego design cluster in producing clean and high-paying jobs the cluster ranks second only after telecommunication and technology, highlighting its potential in thriving the economic growth of the entire region. Furthermore, the San Diego county was the second largest operator in the design industry with a total of 18,531 jobs, behind only at Orange County. It follows that, it proved to have a strong base of design service jobs together with an unquestionable room for growth (I.D.E.A. District, 2011).

Regarding the design firms' location, there were a variety of entrepreneurial and established companies, that can be grouped in five macro categories, which were spread across the wide reach of the overall county, and a particular concentration in the downtown area was observed (Figure 3). The clustering of cultural institutions and design businesses has naturally created an ecosystem of collaboration and innovation in Downtown San Diego, which suggested the opportunity to build a vibrant commercial and residential hub, anchored by them (Figure 4).

Therefore, the I.D.E.A. District was conceived as a vibrant, urban neighbourhood acting as a magnet for a community composed of designers, architects, scientists, students, engineers and artists whose economic function and personal passion is to create new designs, new technology, and new creative content.

Six have been the pillars of the vision: The I.D.E.A. District is seen as ever-changing, with the synergy of creative individuals and firms building off each other's thoughts and ideas. The compact, transit-friendly, mixed-use development can achieve high sustainability standards through the adoption of green infrastructures and building technologies in order to reduce the neighbourhood's carbon footprint while saving long-term energy costs and creating healthy environments for workers and residents. A key component of the District is its ability to act as a stage for designers and innovative new concepts: the outdoor is seen as a public urban laboratory for pioneering ideas in design, art, education, entertainment. Old industrial spaces are considered precious structures to host innovative activities being well-suited for adaptive reuse. At the same time, the building architecture should communicate the creative content within and be open and transparent to involve the surround into the inside creative environment. Community space plays also a key role in providing a platform for experimentation and expression within the District; therefore, a network of parks and plazas is ensured within a short walk of every resident and employee, where performances, exhibits, and art installations can occur allowing informal interactions.

The overarching goal of the vision was to attract and retain young, creative and highly educated 24-35-yearold-individuals, as known as "young and restless" (Cortright, 2006), who represents the tomorrow's workforce and entrepreneurs, essential ingredients of a successful innovation ecosystem (Urban Land Institute, 2012). Therefore, the I.D.E.A. District vision stems from the need to make Downtown attractive for the emerging workforce in order to bring jobs back to the city centre, by creating an innovative design cluster.

\section{Case study results}

Downtown San Diego stands for the attempt to create a pulsating city centre driven by a "Design jobs cluster, nourished by Education, enriched by the Arts and focused on Innovation" (I.D.E.A. District, 2017). Specifically, recalling the 1980s general strategy of the Centre City Development Corporation aiming at revitalising the "dormitory" character of Downtown San Diego, two developers in 2010 brought forward the I.D.E.A. District. Thus,

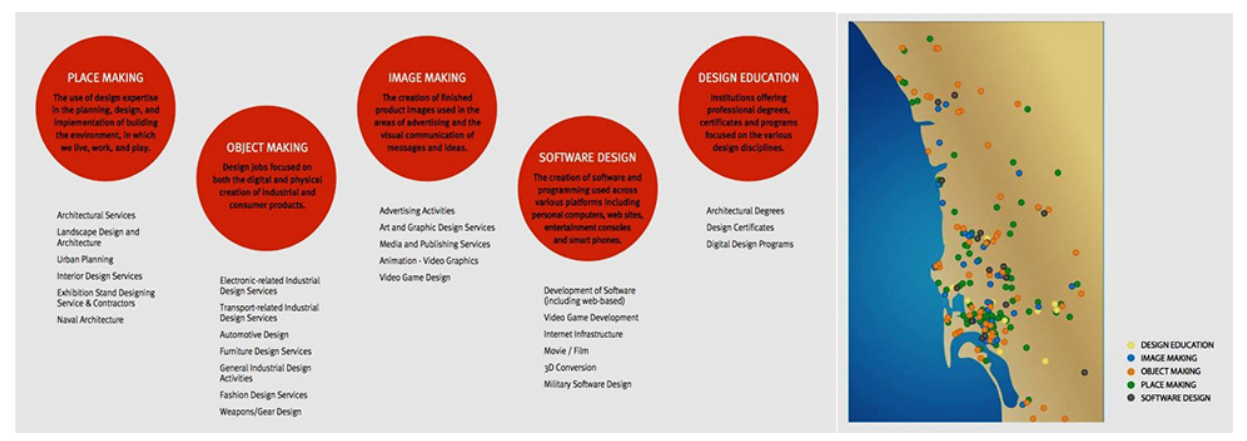

Figure 4. The 5 components of a design cluster and its location within the San Diego County (I.D.E.A. District, 2011) 
with the intention to make the downtown attractive for the emerging innovation workforce and bring jobs back to the city centre, the I.D.E.A. vision targeted 35 blocks located in the Upper East Village neighbourhood, where the growing design businesses and educational institutions, together with the availability of urban land, were the main ingredients for creating a new design industry cluster framework.

\subsection{Start-up}

It has to be acknowledged that coordinated actions between city government, landowners and developers are critical to transform the vision of an innovation district into reality. However, starting from the analysis of the start-up stage, the San Diego experience depicted unbalanced efforts since the private sector carried out the most important enabling interventions. Indeed, the I.D.E.A. Partners have been the lead agents in the process of change, by replacing the public sector in understanding the city's competitive advantage, identifying the innovative industries to attract for spurring the critical mass capable of driving economic growth, and selecting the most appropriate location for the future development. Furthermore, in order to build consensus around the principles of the plan, they started to develop a shared vision by involving residents, local businesses and civic leaders. Given the little support shown by the local administration from the outset, the involvement of both the community and the innovators, through an effective outreach strategy, turned out to be crucial. City leaders, on the contrary, failed in defining a long-term strategy tailored to the innovation district needs, as well as in simplifying the urban regulations to speed up all the stages of the planning process.

\subsection{Activation}

The private sector leadership was paramount also in the Activation stage of the District. The mixed-use IDEA1, the first building block in the East Village neighbourhood, represents a joint venture development intended to act as a magnet to attract new tenants and investments into the area. Besides this catalytic investment, for the purpose of shaping a critical mass of innovators and attracting additional companies, significant were the efforts of some anchor firms, universities and innovation hubs (such as the Qualcomm Institute) to settle in the district. Partnerships with other investors and developers have been established as well, leading to further development initiatives, such as the Makers Quarter, for fostering the work-liveplay environment required by start-ups, tech companies, and young talents. More importantly, the I.D.E.A. Partners never disrupted the communication with the community, and adopted a tactical urbanism approach, re-shaping the image of the neighbourhood as a more vibrant location through the strategic use of citizen-led cultural projects and events. Specifically, by inviting both the existing residents and the next generation of potential innovators to raise awareness and experience a creative East Village neighbourhood, but also strengthen social bonds, this strategy was essential to test new ideas with the users continuously, and better define the district vision. On the other hand, this strategy was an effective way to create value and strengthen the sense of place within the community, which led to an increase in the demand for the district itself. However, also in this stage the public sector role can be defined somehow idle. Indeed, the East Village neighbourhood did not benefit from a centralized plan and the zoning requirements of the Community Plan 2006 remained unchanged. The city government did not undertake any effort to facilitate the mixed-use development and make the area more attractive to new businesses, since neither financial tool, nor system of development rights have been used in order to encourage strategic firms to re-locate in the area.

\subsection{Maturing}

The I.D.E.A. District is still at the very beginning of the third stage of its development, therefore, the actions further implemented by the public and private sector can be deduced by the current state of affairs. The public actors are now starting to show their interest in the innovation processes going on in the downtown area and are facilitating the move of educational institutions, such as the UCSD (personal communication, May 16, 2017). The UCSD Extension is, then, facilitated by the city government that put some regulations and guidelines given its ownership of a small property within the block subject of intervention.

\section{Discussion}

The case study of the I.D.E.A. District has been analysed through the application of a framework for assessing the roles of public and private sectors throughout the different stages of the innovation district development. Following the investigation of the secondary data collected and the direct analysis performed, some issues related to the development project put in place within the East Village neighbourhood in San Diego will now be highlighted.

\subsection{The lack of PPP}

The I.D.E.A. District provides clear evidence that the multi-stage strategic approach, implemented by the concerted actions of public and private sectors, is crucial to create and nourish a successful innovative environment. Undoubtedly, the land ownership issue played a key role in discouraging any collaboration between the actors: since the city owned a considerably small portion of downtown land (around the 20 per cent), the prevailing private interests led the entire intervention of redevelopment within the East Village neighbourhood. The lack of a private public partnership turned out to be challenging for the district, resulting in a sluggish development as a whole. Some structured observations allowed to collect primary data that were precious to highlight the fact 
that the partnership with the San Diego city government, most of the time, does not accelerate urban regeneration processes, but leads to even more time-consuming and complex practices due to a lot of red tape. It follows that, the series of vibrant initiatives currently happening in the area, reflecting mainly the efforts of developers and private investors, are a concrete expression of the values on which the innovation district is built, since they act individually and do not take advantage from co-locating, hampering the ecosystem of collaboration and innovation to occur.

\subsection{The role of city}

Given the shift of the geographical distribution of innovation from suburban corridors and science parks to downtown areas, cities must constantly reinvent themselves in order to provide an environment that is conducive to innovation and remain competitive in the 21st century globalized economy. Although, on the one hand downtown San Diego naturally provides a compact urban structure which is vital for productive collisions to take place between firms, people, capital, and ideas - on the other hand the city government has not been a lead partner on boosting the innovation ecosystem by providing the institutional and regulatory framework that would have managed the re-urbanization and influenced the number of innovative activities through the adoption of designated policies. As a result, the lack of innovation-oriented economic urban policies and economic development measures to foster the ecosystem preconditions and control the city's urban regeneration has proved crucial to the attraction and retention of anchor institutions and the development of human capital. Indeed, the high rents and the lack of any tax incentives are the main factors discouraging companies from locating in this area.

\subsection{The role of real estate}

All the interventions undertaken within the I.D.E.A. District are driven by private interests, since the private actors tried to redevelop the shells left empty by previous private interests due to the economic downturn. The innovation economy, indeed, took over from the manufacturing industry sector located in the downtown area, and the role of real estate turned out to be essential for its physical transformation. The reasons are well explained by the rate and the capability of the real estate to adapt to the new innovation market requirements, determining a strong competitive advantage for the innovation system in which they operate (Clark \& Moonen, 2015).The new users' needs significantly differ from the previous ones; given the talents quest for urban settings that offer the unique experience of attractive and vibrant 24/7 neighbourhoods to work, live, and play, it is up to investors and landowners to provide spaces characterized by an efficient transportation system that brings together a mix of public spaces, cultural amenities, creative work environments and a targeted housing offer. Therefore, the set of private initiatives currently happening in the East Village neighbourhood pursue the same objective, although they operate independently from one other, to deliver an inspiring and accessible environment to attract talents and foster innovation. In addition, The I.D.E.A. Partners continuous communication with the community through the tactical urbanism approach has to be highlighted, since cultural projects and events turned out to be paramount in tailoring the district vision to the specific need of the future users, creating value and sense of place within the community, at the same time.

\section{Conclusions}

Given the shift of the geographical distribution of innovation from suburbs to urban areas, cities must constantly reinvent themselves in order to provide an environment that is conducive to innovation and push on competition in the 21st century globalised economy. Downtown San Diego naturally provides a compact urban structure, which is vital for productive collisions between firms, people, capital, and ideas to take place. Yet, on the other hand, the city government has not been a leading partner in boosting the innovation ecosystem by providing the necessary institutional and regulatory framework for managing the re-urbanisation and influencing the innovative activities through the adoption of designated policies. Moreover, since the city owned a considerably small portion of downtown land, the prevailing private interests led the entire intervention of redevelopment. Thus, the land ownership issue played a key role in discouraging any collaboration between actors. It also played an important role for the spatial innovation, since the prevailing private ownership of the already consolidated urban fabric of Downtown San Diego does not allow to read a clear innovation spatial matrix, except for some regeneration interventions. The innovation economy in the I.D.E.A. District, took over mainly from the manufacturing industry sector located in the downtown area, and the role of real estate turned out to be essential for its physical transformation. The reasons are well explained by the ability of the real estate actors to adapt to the new innovation market requirements, determining a strong competitive advantage for the innovation system in which they operate. This explains why the set of private initiatives, although operating independently, pursues the same objective to deliver an inspiring and accessible environment that attracts talents and fosters innovation. The tactical urbanism turned out to be paramount in tailoring the district vision to the specific needs of the future users, creating value and sense of place within the community.

The I.D.E.A. District is a living laboratory that is assuming a metropolitan connotation, becoming a pretext for physically regenerating the areas and expanding the city, thus, there is innovation going on in the District, but it is no longer the primary focus. This is reflected by the rocketing real estate prices that create a tension between the economic growth driven by innovation and the unsustainable negative externalities generated by the Innovation District model. The benefits tend to concern 
mainly middle- and upper-class people, widening the gentrification gap and worsening also the already critical situation linked to the homeless issue. Thus, overall, the business model of Innovation Districts, becoming unaffordable to the most and favouring the concentration of poverty in a few areas, adds to the effects of the existing high poverty rate.

It emerges that the Innovation District model is a great tool for urban flourishing, that, being place-based, cannot be started in a vacuum, because it got attached to a specific urban ecosystem. For the purpose of following the new strategies of the innovation economy in a sustainable way, it emerges the necessity of having a leading-edge anchor institution to catalyse the critical mass of innovators and companies. The innovation-oriented economic urban policies and economic development measures to foster the ecosystem preconditions and control the city's urban regeneration, as well, are crucial to the development of the model, since the high rents and the lack of any tax incentives are the main factors that discourage companies from locating in the district.

Thus, the case study provides evidence that the multistage strategic approach, implemented by the concerted actions of public and private sectors, is essential to create and nourish a successful innovative environment. The support of the public actors is vital for the coordination of the initiatives and the sustainability of the model, helping to avoid the unintended consequences linked to the phenomenon of aggregation of talents, such as the rocketing real estate prices and the consequent gentrification. Public initiatives, including zoning and investments, are fundamental also for supporting diversity, which is a necessary ingredient of the Innovation District model for triggering innovation.

Overall, the Innovation District model can function as test sites for urban planning strategies, assisting the public sector policies and the built-environment goals. Thus, the implementation of these new innovation-oriented urban regeneration initiatives within urban growth strategies, is important for enhancing competitiveness and improving the liveability of places, by providing solutions for a more efficient land use. Yet, with a hands-off approach adopted by the public sector, it could not be considered a good sustainable urban design practice.

\section{Acknowledgements}

The authors thank Professor Carmelina Bevilacqua (Mediterranea University of Reggio Calabria, Italy) for her precious support. This contribution has been developed thanks to the research experience at the San Diego State University, part of the research project MAPS-LED (Multidisciplinary Approach to Plan Smart Specialization Strategies for Local Economic Development) which has received funding from the European Union's Horizon 2020 research and innovation program under the Marie Skłodowska-Curie grant agreement number 645651.

Finally, the authors want to thank the people closest to them, who always give their priceless support.

\section{Funding}

This contribution has been developed thanks to the research experience at the San Diego State University, part of the research project MAPS-LED (Multidisciplinary Approach to Plan Smart Specialization Strategies for Local Economic Development) which has received funding from the European Union's Horizon 2020 research and innovation program under the Marie Skłodowska-Curie grant agreement number 645651.

\section{References}

Asheim, B. T., \& Gertler, M. S. (2006). The geography of innovation: Regional innovation system. The Oxford Handbook of Innovation.

https://doi.org/10.1093/oxfordhb/9780199286805.003.0011

Autio, E., \& Thomas, L. D. W. (2014). Innovation ecosystems: Implications for innovation management? In The Oxford handbook of innovation management. Oxford University Press. https://doi.org/10.1093/oxfordhb/9780199694945.013.012

Clark, G., \& Moonen, T. (2015). Technology, real estate, and the innovation economy. Urban Land Institute.

Community Local Urban Development Laboratory. (2017). MAPS-LED project: Multidisciplinary approach to plan smart specialization strategies for local economic development. https://www.cluds.unirc.it/project/project-mapsled/

Cortright, J. (2006). Making sense of clusters: Regional competitiveness and economic development. Metropolitan Policy Program at Brookings.

Dahlman, C. (2007). Technology, globalization, and international competitiveness: Challenges for developing countries. In Industrial development for the 21st century: Sustainable development perspectives. Department of Economics and Social Affairs.

Delgado, M., Porter, M., \& Stern, S. (2014). Cluster, convergence and economic performance. Research Policy, 43(10), 17851799. https://doi.org/10.1016/j.respol.2014.05.007

DesignSingapore Council. (2008). Strategic blueprint of the DesignSingapore initiative. DesignSingapore Council, Ministry of Information.

Etzkowitz, H., \& Leydesdorff, L. (1997). Universities in the global knowledge economy. Continuum.

Feldman, M. (1994). The geography of innovation. Kluwer Academic Publishers. https://doi.org/10.1007/978-94-017-3333-5

Florida, R., Adler, P., \& Mellander, C. (2017). The city as innovation machine. Regional Studies, 51(1), 86-96. https://doi.org/10.1080/00343404.2016.1255324

Florida, R. (2008). Who's your city?: How the creative economy is making where to live the most important decision of your life. Basic Books.

Giuffrida, G., Clark, J., \& Cross, S. (2015). Putting innovation in place: Georgia Tech's innovation neighbourhood of Tech Square. https://www.gatech.edu/sites/default/files/documents/georgiat-tech-putting-innovation-in-place.pdf

Gobble, M. (2014). Charting the innovation ecosystem. ResearchTechnology Management, 57(4), 55-59.

I.D.E.A. District. (2011). District vision. http://www.ideadistrictsd.com/vision/

I.D.E.A. District. (2017). District vision. http://www.ideadistrictsd.com/vision-document-available-now/

Inkinen, T. (2015). Reflections on the innovative city: Examining three innovative locations in a knowledge bases framework. Journal of Open Innovation: Technology, Market, and Complexity, 1, 1-23. https://doi.org/10.1186/s40852-015-0009-5 
Institute for Transportation and Development Policy. (2019). The transformative power of tactical urbanism in the global South. https://www.itdp.org/event/power-of-tactical-urbanism/

Katz, B., \& Wagner, J. (2014). The rise of innovation districts: A new geography of innovation in America. Brookings Institution.

Lydon, M., \& Garcia, A. (2015). Tactical urbanism: Short-term action for long-term change. Journal of the American Planning Association, 81(2), 154-155.

https://doi.org/10.1080/01944363.2015.1054708

Metcalfe, S., \& Ramlogan, R. (2008). Innovation systems and the competitive process in developing economies. The Quarterly Review of Economics and Finance, 48(2), 433-446. https://doi.org/10.1016/j.qref.2006.12.021

Montgomery, D. C. (2012). Introduction to statistical quality control (7th ed.). Wiley.

Moore, J. (1996). The death of competition: Leadership \& strategy in the age of business ecosystems. HarperCollins Publisher.

Mulas, V., Minges, M., \& Applebaum, H. (2015). Boosting tech innovation ecosystems in cities: A framework for growth and sustainability of urban tech innovation ecosystem. The World Bank.

Parisi, L. (2017). Creative and cultural industries within port environments: A smart specialisation strategy for Southern Italy [Unpublished $\mathrm{PhD}$ thesis]. Mediterranea University.
Pfeifer, L. (2014). The planner's guide to tactical urbanism. Regina Urban Ecology. https://reginaurbanecology.files.wordpress. com/2013/10/tuguide1.pdf

Sallet, J., Paisley, E., \& Masterman, J. (2009). The geography of innovation: The federal government and the growth of regional innovation clusters. Science Progress.

San Diego. (2010). Connect Innovation Report (4th quarter). https://library.ucsd.edu/dc/object/bb3791085d/_1.pdf

Shearmur, R. (2012). Are cities the font of innovation? A critical review of literature on cities and innovation. Cities, 29(Suppl. 2), S9-S18. https://doi.org/10.1016/j.cities.2012.06.008

Urban Land Institute. (2012). Principle of creating innovation economies: A 21st century economic development tool. San Diego.

West, D. M. (2011). Technology and the innovation economy. Center for Technology Innovation at Brookings.

\section{Notations}

Abbreviations

I.D.E.A. - Innovation, Design, Education, Arts;

UCSD - University of California San Diego. 